\title{
DOI https://doi.org/10.30525/978-9934-26-042-1-9
}

\section{СПЕЦИФІКА ВИКОРИСТАННЯ СОЦІАЛЬНИХ МЕРЕЖ ДЛЯ ФОРМУВАННЯ КОРПОРАТИВНОГО ІМІДЖУ ОРГАНІЗАЦЇ̈}

\author{
Парубець О. М. \\ кандидат наук із соиіальних комунікацій, \\ асистент кафедри реклами та зв 'язків з громадськістю \\ Інстутут журналістики Київського національного університету \\ імені Тараса Шевченка \\ м. Київ, Украӥна
}

В сучасному постмодерному світі особливого значення набувають символічні конструкти, які втілюють в собі певні нематеріальні цінності, однак мають конкретну ринкову вартість. Одним 3 таких конструктів, безперечно, є корпоративний імідж як колективний образ організації, який формується в громадськості під впливом тієї інформації, яку ретранслює організація в зовнішній світ.

Американська дослідниця Б. Джі підкреслює, що корпоративний імідж не стільки і не тільки втілює інформацію про продукцію організації, а більшою мірою сповіщає про стандарти поведінки та професійність представників організації. Вона відзначає, що такий підхід громадськості до сприйняття організації є доволі спрощений, однак саме 3 нього починається знайомство з організацією. Позитивний імідж прокладає шлях до репутації в так більш широких і суттєвих сферах як, до прикладу, якість продукції.

Інтернет відкрив нові можливості для формування та просування корпоративного іміджу, адже уможливив симультанну безпосередню комунікацію з цільовими аудиторіями без посередників. Скористатися всіма перевагами та можливостями такої комунікації можуть тільки ті організації, які не тільки розуміють особливості нашої цифрової доби, але й здатні швидко адаптуватися до ії тенденцій.

В глобальному дослідженні цифровізації, підготовленому спільно фахівцями DataReportal, WeAreSocial та Hootsuite, наведено дані про те, що у 2020 році глобальну мережу використовували 4,54 мільярди людей, що становить майже $60 \%$ всього населення Землі. При цьому щомісячна аудиторія соціальних мереж зросла до 4 млрд користувачів, тобто акаунти у різних соціальних мережах мають 53\% населення 
нашої планети. Швидкість реєстрації нових користувачів соціальних мереж становить 2 мільйони нових користувачів щодня або 14 людей за секунду. Людина в середньому проводить в інтернеті 6 годин 43 хвилини на доби, тобто приблизно $40 \%$ свого часу своєї денної активності. Половину цього часу люди виходять в Інтернет, використовуючи смартфон [7].

Зважаючи на це, використання мережевого інструментарію зв'язків 3 громадськістю перетворилось на актуальну вимогу часу. Саме тому варто концептуалізувати поняття соціальних мереж. Вперше цей термін був запропонований Д. Барсом, який розумів соціальні мережі як сукупність людей та звязків між ними [6]. В сучасному суспільствознавчому дискурсі цей термін трактують через призму Інтернеткомунікації, що реалізується з допомогою різноманітних онлайн-сервісів. Характерними ознаками соціальних мереж Б. Вахула $\epsilon$ вважає спілкування у реальному часі без просторових обмежень, локалізацію за певними спеціалізованими чинниками, існування спеціального типу мовлення, створення власного віртуального образу користувачем на основі використання текстуальних та графічних засобів [1]. Соціальні мережі використовуються для того, щоб розширити коло спілкування, слідкувати за діяльністю інших користувачів та висловлювати власні позиції 3 актуальних соціальних проблем. Вони дозволяють підтримувати зв'язок на відстані одночасно з великою кількістю людей, а тому потенційно будь-яка онлайн-комунікація може втілитись в спільні заходи поза глобальною мережею.

Незважаючи на те, що соціальні мережі більшістю користувачів сприймаються насамперед як засіб особистого спілкування, маркетологи давно оцінили їх переваги в комерційних комунікаціях. На відміну від маркетологів, PR-фахівці не пропонують через соціальні мережі товари та послуги, а вибудовують спілкування 3 цільовими аудиторіями так, щоб у них склався стійкий позитивний імідж організації. O. Сторожук, аналізуючи тренди реклами та PR, наголошує на тому, що таргетована реклама в соціальних мережах втратила свою актуальність 22020 році. Незважаючи на те, що люди в час локдауну активно використовували соціальні мережі для пошуку розваг та позитиву, а тому раціональний контент втрачає свою актуальність [5].

Основою використання соціальних мереж в побудові та просуванні корпоративного іміджу є розуміння загальної комунікаційної стратегії організації. Ведення акаунтів та груп в соціальних мережах $€$ продовженням та доповненням інших інструментів сучасних зв'язків 3 громадськістю - подієвої комунікації, офіційного сайту, комунікацій з медіа. Саме загальна спрямованість та стилістика стратегічних 44 
комунікацій організації визначає орієнтири використання соціальних мереж: вибір самої соціальної мережі, формат взаємодії (корпоративний акаунт створення групи, персональні сторінки представників організаціi), спрямування контенту та частота його генерації.

Вибір соціальної мережі є відправною точкою роботи, яка включає в себе розуміння специфіки соціальної мережі, ії можливості та обмеження. Серед організацій часто панує принцип чим більше, тим краще. За цим принципом створюються акаунти у всіх доступних соціальних мережах. Такий підхід, на наш погляд, є хибним, адже вимагає надто багато організаційних та фінансових зусиль від організації, адже це передбачає значну кількість організаційних та фінансових ресурсів. Іноді можна побачити, що організації, економлячи ці зусилля, просто дублюють одні і ті ж повідомлення в соціальних мережах, навіть не адаптуючи їх. Така штучність та недбалість зчитується цільовими аудиторіями, інтерес яких невпинно падає. Натомість значно краще обрати саме ту соціальну мережу (одну або кілька), яка максимально відповідатиме демографічним, психографічним, культурним характеристикам цільових аудиторії організації та iii інформаційним потребам. Наприклад, у Facebook фактично однакова кількість чоловіків та жінок та однорідний розподіл за віком. В Instagram переважає жіноча аудиторія, тоді як в Telegram в основному чоловіча [3].

На сьогодні переважна кількість організацій усіх форм власності обирають формат єдиного корпоративного акаунту. При цьому його назва часто відповідає назві самої організації. Це забезпечує ідентифікацію акаунта 3 організацію, проте робить спілкування 3 цільовими аудиторіями знеособленим. В такому випадку, як правило, комунікація ведеться від першої особи множини, що дезорієнтує відвідувачів акаунту. Використання персональних акаунтів для представників організації робить спілкування більш адресним та відповідальним, однак буває складно провести чіткий водорозділ між персональною та корпоративною інформацією.

Незважаючи на те, який тип акаунту та соціальну мережу використовує організація, важливо пам'ятати про кілька загальним правил комунікації в соціальних мережах. Першим правилом є єдина стилістика всіх соціальних мереж, що досягається використанням корпоративного кольору або поєднанням кольорів, впізнаваних форм, корпоративного персонажу тощо. Важливою $є$ увага до використання лексики, яка повинна бути зрозумілою широкому колу користувачів інформації. Користувачі соціальних мереж звикли до швидкої реакції на свої запити, а тому організаціям варто подбати про те, щоб кожне 
звернення чи питання користувачів отримувало оперативну офіційну відповідь.

I. Семененко наголошує, що в контексті спілкування у соціальних мережах потрібно акцентувати увагу і на юридичні аспекти цього явища, зокрема: ідентифікацію користувачів мережі «Інтернет», посилення відповідальності за дотримання авторських прав, цифрову безпеку, кібергігієну та забезпечення безпеки доступу до баз даних, нормативно-правове врегулювання використання офіційної символіки у соціальних мережах, а також питання моралі і цензури [4].

Враховуючи викладене вище, можна зробити висновок про те, що використання соціальних мереж для формування та просування корпоративного іміджу організації є актуальним трендом інструментів побудови стратегічних комунікацій. Глобалізація та цифровізація стимулює організації усіх форм власності інтегруватись у соціальні мережі, однак зберігати при цьому свій унікальний візуальний стиль та корпоративний ідентичність.

\section{Література:}

1. Вахула Б. Я. Соціальні інтернет-мережі, їхні функції та роль у формуванні громадянського суспільства. Вісник Львівського університету. Серія соџіологічна. Львів, 2012. № 6. - С. 311-319. URL: http://nbuv.gov.ua/UJRN/Vlnu_sociology_2012_6_36

2. Джи Б. Имидж фирмы. Планирование, формирование, продвижение. СПб, 2000. 224 с.

3. Сейчас люди сидят в Facebook на 10 минут больше, чем в 2018. URL: https://l-a-b-a.com/blog/685-kakie-socseti-predpochitajut-ukraincy.

4. Семененко I.O. Правові механізми використання соціальних мереж у публічному управлінні. URL: http://www.e-patp.academy.gov.ua/ pages/dop/26/files/4e838840-fc56-4d5a-b06b-13cf9f7eb056.pdf

5. Сторожук O. Реклама i PR для бізнесу: антітренди і тренди 2020 https://ua.interfax.com.ua/news/blog/712458.html

6. Barnes J. A. Class and committees in Norwegian island parish. London, 1954. $58 \mathrm{p}$.

7. Digital 2020: Global Digital Overview Url: https://datareportal.com/ reports/digital-2020-global-digital-overview. 